\title{
Interactive comment on "Atmospheric
} observations made at Oliktok Point, Alaska as part of the Profiling at Oliktok Point to Enhance YOPP Experiments (POPEYE) campaign" by Gijs de Boer et al.

Gijs de Boer et al.

gijs.deboer@colorado.edu

Received and published: 20 June 2019

Please see responses to the comments from the reviewers in the attached document. We thank all of the reviewers for their contributions to the improvement of the manuscript. 
Interactive comment on Earth Syst. Sci. Data Discuss., https://doi.org/10.5194/essd-2019-46, 2019.

\section{ESSDD}

Interactive comment 